\title{
CAN INNOVATION BE THE REASON FOR A LONG TERM SURVIVAL?
}

\author{
Bige AŞKUN \\ Refika BAKOĞLU \\ Marmara University, Turkey
}

\begin{abstract}
The purpose of the present study is to explore the innovative characteristics of firms surviving through the ages by using content analysis of their websites. The article proceeds in the following manner: First, we briefly review the literature. Second, we explore innovative characteristics of firms surviving through the ages by using content analysis method. We will be analyzing all firms that are listed in the www.henokiens.com. Henokiens is an association that accepts firms which are at least 200 years of age. The 41 firms from different nationalities were analyzed by content. The validity and the reliability reports and procedures are given. Finally, we provide the research findings and discuss their managerial and theoretical implications.
\end{abstract}

Keywords : Innovation, Survival, Firms surviving through the ages, Innovative characteristics

\section{INTRODUCTION}

There are different approaches for explaining survival of firms like industrial economics, organizational ecology and resource based view. In industrial economics perspective structural factors play vital role such as size and age of firm, and survival also depends on the outcome of a market selection (Cefis and Marsili, 2005: 1168). Cefis and Marsili (2006) analyzed the effects of innovation on the survival probability of manufacturing firms, conditional on firm attributes such as age and size and sector, and found that innovation matters for increasing the survival probability of firms. The role of market selection is seen vital because of imperfect information presence by Javanovic (1982) and of uncertainty due to research and development efforts by Ericson and Pakes (1995). These two studies also indicate survival probability increases with age and size. Similarly, there are other studies that exhibit positive linkage between firm survival and its size and age (Geroski, 1995; Sutton, 1997; Caves, 1998).

This paper aims to achieve by reviewing the literature then make a research about the concept and types of innovation for analyzing to find that whether innovation be a reason for a long term survival or not.

\section{LITERATURE REVIEW}

When overviewing all the studies, survival probability related to age and size means experiences increases the chance of survival over the lifecycle of a firm. In the perspective of industrial economics, firm survival depends also the level of intangible assets and the quality of capital stock. For instance technological capacity measured by research and development and patent statistics (Hall, 1987), and advanced manufacturing technologies (Doms et al., 1995; Colombo and Delmastro, 2001) have higher chance of survival. The other important determinants of survival at industry level according to the industrial economics are the characteristics of demand, such as market size and growth rates (Mata and Portugal, 1994). These studies clearly observe linkage between innovation and survival in industrial economics perspective.

The studies are bringing forward connection between survival and age and size conditionally on age, are also in line with the organizational ecology. Organizational ecology highlights the vital role of organizational strategies, and environmental conditions like the rate of organizational change has effect on organizational strategies Hannan and Freeman (1997). Separate organizations as specialist and generalist occupying a narrow, the first, and a broad, the second, niche in their market for being able to survive. According to the organizational ecology perspective survival is more related to the 
density of the population at the time of founding and throughout the life period of an organization meaning that a firm entering crowded field would have less chance than a firm entering to less competitive area (Carrol and Hannan, 1989; Hannan and Freeman, 1988). Mitchell (1991) stresses the importance of entry timing for firm survival.

Another recent perspective on the firm survival is the resource-based view that emphasizes how firm's stock of tangible and intangible assets including employee's individual skills, and competencies representing firm's collective capacity for undertaking a specific type of activity can develop organizational capabilities and enhance organizational performance. Those working within the "resource based view of the firm" area have been inspired by the work of Selznick (1957) and Penrose (1959), and have suggested that inimitable firm heterogeneity, or the possession of unique "competencies" or "capabilities" may be an important source of strategic advantage (Lippman and Rumelt, 1982; Wernerfelt, 1984; Barney, 1986; Rumelt, 1991; Peteraf, 1993; Amit and Schoemaker, 1993). While resources are the essential building blocks, whether an organization gains a competitive advantage and thereby achieves above-normal returns will be a function of the strategy used to leverage those resources to pursue environmental opportunities (Hofer and Schendel, 1978). For an organizational "competence" to be a source of competitive advantage it must meet three conditions: it must be heterogeneously distributed within an industry, it must be impossible to buy or sell in the available factor markets at less than its true marginal value, and it must be difficult or costly to replicate (Barney, 1986; Wernerfelt, 1986; Peteraf, 1993). Liao, Kickul and Ma (2009) indicate that both the firm's resource stock and integrative capabilities, ability to recognize opportunities as well as to configure and deploy resources, affect its innovation. Additionally, they also found that the relationship between resource stock and innovation is mediated by integrative capabilities. Lieberman and Montgomery (1998) suggested that first mover advantage and resource based review are related conceptual frameworks that can benefit from closer linkage.

According to the resource based view strategies should not be build around external opportunities, but around a company's strengths, on the contrary to the industrial economics approach. Development of difficult-to-imitate competencies and/or on the acquisition of exlusive assets are the main strategic focus in order to gain sustainable competitive advantage. This unique resource base should be used as the strating point of strategy formation with respect to resource based view, which is the opposite of industrial economics and organizational ecology approaches. In order to the resource based view, markets should subsequently be chosen, adapted or created to exploit these specific strengths, and once a company developed a distinctive ability, it is usually difficult for competitors to imitate, and while rivals try to catch up, a company with an initial lead can try to upgrade its competencies in the rase to stay ahead (Collis and Montgomery, 1995; Barney, 1991). As even Porter (1980), being accepted the guru of the industrial economics theory, advocates that a competitive advantage could be sustainable, if it cannot be copied or eroded by the actions of rivals, and is not made redundant by environment developments. As industiral economics and organizational ecology approaches heavily relies on the market dominance and market/industry position, survival of the firm may not step on the solid ground by using these approaches. Just as Hitt, Ireland and Hoskisson asserts that conventional sources of competitive advantage, such as economies of scale and huge advertising budgets, are not as effective as they once were (Hitt, Ireland and Hoskisson, 2005). Since after 1990's, resource based view have changed our mindset of competitive advantage, and resource based view takes innovation as a never ending process. Please see the differences between industrial economics and organizational ecology approaches, as conventional competitive advantage, and resource based competitive advantage in the Table 1 below.

The role of innovation in influencing business performance and survival is widely accepted, but there is only limited evidence identifying any direct relationships between them (Bakoğlu and Aşkun, 2008) as it is indicated above. Although we have tried to make connections among innovation and different perspective in management studies like industrial economics, organizational ecology and resource based view, we were not able to find as many study as it is expected. Cefis and Marsili $(2005,2006)$ also asserted that despite the role attributed to innovation in firm survival, there is little empirical evidence on the relationship between probability of survival and the innovative activities carried out within the firm. Similarly, we have found neither theoretical nor empirical study investigating directly the effect of innovation on firm's long lasting survival, and proving that survival of more than one century old firms may depends on their innovation capacity. On the contrary, some studies indicating family businesses are less likely than none family firms to pursue wealth maximization as their domi- 
nant objective (Sharma, Chrisman and Chua, 1997; Chrisman, Chua and Zahra, 2003; Sirmon and Hitt, 2003).

\begin{tabular}{|c|c|c|}
\hline \multicolumn{3}{|c|}{$\begin{array}{l}\text { Table 1: Novelties on the concept of competitive advantage } \\
\text { introduced by the resource based view }\end{array}$} \\
\hline & Conventional Competitive Advantage & Resource Based Competitive Advantage \\
\hline $\begin{array}{l}\text { Primary Orientation and } \\
\text { Emphasis in Competition }\end{array}$ & Product, Market, Industry & $\begin{array}{l}\text { Resources, Capabilities, Competence, } \\
\text { Business Process, Knowledge }\end{array}$ \\
\hline Strategic focus & $\begin{array}{l}\text { Market/Industry Position } \\
\text { Dominance }\end{array}$ & $\begin{array}{l}\text { Developing Resource Base } \\
\text { Innovation, Distinctive Resources }\end{array}$ \\
\hline Priorty in Competition & Gaining Competitive Advantage & $\begin{array}{l}\text { Gaining Sustainable Competitive } \\
\text { Advantage }\end{array}$ \\
\hline Innovation and Creativity & $\begin{array}{l}\text { Attaining advantageous position } \\
\text { Entering to profitable businesses } \\
\text { Building up Mobility Barriers } \\
\text { Enhancing Bargaining Power }\end{array}$ & $\begin{array}{l}\text { Attaining distinctive resources, competence } \\
\text { development and application for } \\
\text { Changing the Rules of the Game } \\
\text { Rapid competence development }\end{array}$ \\
\hline $\begin{array}{l}\text { Perspective in Strategy } \\
\text { Formulation }\end{array}$ & Outside-in/ Strategic Adaptation & Inside-out/ Strategic Streching \\
\hline Starting Point & Market/ Industry Structure & Firm's Resource Infrastructure \\
\hline $\begin{array}{l}\text { Competitive Weapons in } \\
\text { Business Level Strategy }\end{array}$ & Bargaining Power and Mobility Barriers & Superior Resources and Imitation Barriers \\
\hline $\begin{array}{l}\text { Main Emphasis on the } \\
\text { Corporate Level Strategy }\end{array}$ & $\begin{array}{l}\text { Diverse/unrelated business' portfolio/ Collec- } \\
\text { tion of Shareholdings for profitability and } \\
\text { cash flow allocation }\end{array}$ & $\begin{array}{l}\text { Synergy among higly related businesses/ } \\
\text { value and snergy creation through shared } \\
\text { competence-based (focused) }\end{array}$ \\
\hline $\begin{array}{l}\text { Appraches Towards Strategic } \\
\text { Business Units and Their } \\
\text { Coordination }\end{array}$ & $\begin{array}{l}\text { Highly autonomous } \\
\text { Loosely Coordinated }\end{array}$ & $\begin{array}{l}\text { Highly Entegrated } \\
\text { Tightly Coordinated }\end{array}$ \\
\hline $\begin{array}{l}\text { Assumptions about } \\
\text { Environment }\end{array}$ & Predictible, Slowly Changing & Unknown, Dynamic \\
\hline Assumptions about Firms & $\begin{array}{l}\text { Firms are actors which try to gain opportuni- } \\
\text { ties from their environment or/and enable } \\
\text { themselves to catch this opportunities by } \\
\text { attaining necessary resources. }\end{array}$ & $\begin{array}{l}\text { Firms, and their resources and } \\
\text { competencies are heterogenous. Firms } \\
\text { compete based on these distinctive } \\
\text { resources. }\end{array}$ \\
\hline
\end{tabular}

Source: Bakoğlu, R. (2003) "Kaynak Bazlı Firma Teorisi Kapsamında Değişen Rekabet Avantajı Kavram ve Anlayışı (Changing Competitive Advantage in Frame of the Resource-Based Firm Theory)", İ.Ü. İşletme Fakültesi Dergisi, 32(1), 65-76.

Only Koiranen's article (2002) discusses firms that over 100 years of age may still be active entrepreneurially in business due to their values and family characteristics, when doing literature search through the online databases. There are other studies that may be indirectly linked to this paper's purpose of searching for the linkage between firms' survival more than one century and innovation, like Jovanovic's (1982) theory of 'noisy selection', and Pakes and Ericson's model (1998) whose concerns are not the same as this paper. In Jovanovic's model, firm dynamics depend on the learning process that enables firms to discover and adapt to their particular level of efficiency, given the existence of asymmetries in efficiency and imperfect information. Over time, firms discover their levels of efficiency through operating in the industry. Ericson and Pakes (1995) extended Jovanovic's model to include the investments of individual firms on research and development. This model contrasts a process of 'active learning' to the process of 'passive learning' in Jovanovic's model, where firm efficiency levels are assumed to be constant over time (Pakes and Ericson, 1998). In Ericson and Pakes's model, firms explore the space of technological opportunities by actively investing in research, and by doing so they improve their efficiency and profitability; and ultimately their chances of survival.

Although in literature, some of the studies of innovation take innovation as a basis for the survival and means of sustainable competitive advantage, none of the articles we found indicated that innovation is 
the reason for firms' long lasting survival. Our research question starts from this point; it would be interesting to explore whether the more than one century old firm' survival depends on innovation.

\section{METHOD}

The research is an exploratory qualitative research in its nature since the research objectives are not investigated much in the literature, and content analysis is chosen as a research method considering the objectives. Content analysis is a necessary tool in the study as purpose of the research is to explore whether the firms surviving through the ages sustain due to their innovative capacity. Our main question is that can one clearly observe that the firms surviving through the ages stress innovation on a verbal level by content analyzing their web sites. Content analysis is the only appropriate research method as the main purpose of the research is to what extent these ages firms differ from the rest on a "verbal level" not on the operational level assuming if they are the best they should give a sign of high level awareness on their websites even though all written material may represent ideals besides it would be almost impossible to enter to the 41 leading companies with the limited budget and time. The population of this study is composed of firms surviving through the ages of the global market. The 41 firms which survive through the ages will be content analyzed from the www.henokiens.com website. Each firm's "Home page" was accessed using this web address and www.google.com. After examining each firm's "Home page" to determine the presence or absence of an innovation, then clicked on the firm's web page and likewise examined it.

Content analysis was done by examining the Henokiens' web sites and each firm's own web pages. Each firm's own web page is read and taken notes in details by clicking on all the headlines such as Company today, About Us, Group, expertise, press, profile of our firm, Distribution partners, News, Sustainability, investment service, products, communication, Funds Awards, Activities, General presentation, Historic, fabric procedure, the family, identity, resellers, images, Fleet, Galleries, Links, Contacts, Milestones, Contracts, Write house, Privacy, Help.

\section{LIMITATIONS OF THE STUDY}

Two limitations are present and need to be considered when interpreting the results of the research. First of all, the information and messages released online by organizations are one-sided declarations, and it is not guaranteed that they are applied and realized in the real life. This may limit the generalizability of the study. Taking into consideration this point, we limit our research with only the innovation concept.

Second limitation in this study is about the measurement of the information gathered. The "contents" of the online innovation concept provided and the "frequency" of the items are the most important information this study bases on. This type of evaluation may disregard the weight and importance of the information provided. Innovation concept was explored either Henokiens or Firm's web pages.

\section{VALIDITY OF THE RESEARCH}

To ensure validity of the research, semantic validity has been taken into account. In order to be done semanticly valid study, each researcher independently and individually categorized the items of innovation concept, and the independent sorter examined the themes, made discussions and the themes have been placed under same categories with an agreement on a final categorization in the content analysis process.

\section{POPULATION AND SAMPLING}

The population of this study is composed of Henokiens. It is an association of family and bicentenary companies, the Henokiens intend to enlarge their family circle. Today, there are 41 members: 15 Italian, 12 French, 3 German, 2 Dutch, 1 from Northern Ireland, 5 Japanese, 1 Belgian and 2 Swiss. According to Henokiens Page; In 1981, recognising and co-opting each other, they formed a group, creating a restricted and rigorous international organization. Henokiens Association membership criteria are: company longevity - a minimum age of 200 years - and permanence - the family must be owner of the company or the majority share holder - one member of the founder must still manage the company or be a member of the board - and the company must be in good financial health. 
Journal of Global Strategic Management | V. 4 | N. 2 | 2010-December | isma.info | 113-125 | DOI: 10.20460/JGSM.2010415829

Table 2: General Information about the Population

\begin{tabular}{|c|c|c|c|c|c|}
\hline Country & Name of the Firm & Web Page & \begin{tabular}{|l|} 
Web page in \\
English
\end{tabular} & \begin{tabular}{|l|} 
Total/ \\
Sample
\end{tabular} & $\begin{array}{l}\text { \% of } \\
\text { Population }\end{array}$ \\
\hline \multirow[t]{3}{*}{ Germany } & Friedr. Schwarze & http://www.schwarze-schlichte.de & No & $3 / 2$ & 7,32 \\
\hline & Möllergroup & http://www.moellergroup.com & Yes & & \\
\hline & J.D. Neuhaus & http://www.jdn.de & Yes & & \\
\hline Belgium & D'ieteren & http://www.dieteren.com & Yes & $1 / 1$ & 2,44 \\
\hline \multirow[t]{12}{*}{ France } & $\begin{array}{l}\text { Banque J.P. Hottinguer \& } \\
\text { Cie }\end{array}$ & http://www.hottinguer-jph-cie.com & Yes & $12 / 8$ & 29,27 \\
\hline & $\begin{array}{l}\text { Baronnie De } \\
\text { Coussergues }\end{array}$ & http://www.chateaudecoussergues.com & Yes/ N.A. & & \\
\hline & Delamare Bois & http://www.delamare-bois.com & No & & \\
\hline & Sfco-Maison Gradis & There is no web page & No & & \\
\hline & Hugel \& Fils & http://www.hugel.com & Yes & & \\
\hline & Louis Latour & http://www.louislatour.com & Yes & & \\
\hline & Editions Henry Lemoine & http://www.editions-lemoine.fr & Yes & & \\
\hline & Mellerio Dits Meller & http://www.mellerio.fr & Yes & & \\
\hline & Revol & http://www.revol-porcelaine.fr & Yes & & \\
\hline & Jean Roze & There is no web page & No & & \\
\hline & Thiercelin & http://www.thiercelin.com & Yes & & \\
\hline & Viellard Migeon \& Cie & http://www.viellardmigeon.com & Yes & & \\
\hline Ireland & $\begin{array}{l}\text { William Clark And Sons, } \\
\text { Ltd. }\end{array}$ & http://www.wmclark.co.uk & Yes & $1 / 1$ & 2,44 \\
\hline \multirow[t]{15}{*}{ Italy } & Amarelli & http://www.amerelli.it & Yes & $15 / 13$ & 36,59 \\
\hline & Augustea & http://www.www.augustea.com & Yes & & \\
\hline & Barovier\&To & http://www.barovier.com & Yes & & \\
\hline & Beretta & http://www.beretta.com & Yes & & \\
\hline & Cartiera Mantovana & http://www.cartieramantovana.it & Yes & & \\
\hline & $\begin{array}{l}\text { Fonderia Campane } \\
\text { Colbachini \& Figli }\end{array}$ & http://www.fonderiacolbachini.it & N.A. & & \\
\hline & Confetti Mario Pelino & http://www.pelino.it & Yes & & \\
\hline & CRESPI 1797 S.P.A. & http://www.crespi1797.it & Yes & & \\
\hline & Ditta Bortolo Nardini S. P. A & http://www.nardini.it & Yes & & \\
\hline & $\begin{array}{l}\text { Giobatta \& Piero Garbellotto } \\
\text { S.P.A }\end{array}$ & http://www.garbellotto.it & Yes & & \\
\hline & FALCK S.P.A. & http://www.falck.it & Yes & & \\
\hline & LANIFICIO G.B. Conte Spa & http://www.gbconte-galtes.it & N.A. & & \\
\hline & Monzino 1750 & http://www.monzino.it & Yes & & \\
\hline & Piacenza & http://www.piacenza1733.it & Yes & & \\
\hline & Torrini G.S.R.L. & http://www.torrini.it & Yes & & \\
\hline \multirow[t]{5}{*}{ Japan } & Akafuku & http://www.akafuku.com & Yes/limited & $5 / 4$ & 12,20 \\
\hline & Gekkeikan Sake Company, & http://www.gekkeikan.co.jp & Yes & & \\
\hline & Hoshi & http://www.ho-shi.co.jp/jiten/Houshi_E & Yes & & \\
\hline & Okaya & http://www.okaya.co.jp/ & Yes & & \\
\hline & Toraya & http://www.toraya-group.co.jp/ & Yes & & \\
\hline \multirow[t]{2}{*}{ Netherlands } & De Kuyper & http://www.dekuyper.com & Yes/limited & $2 / 1$ & 4,87 \\
\hline & Van Eeghen & http://www.vaneeghen.com & Yes & & \\
\hline \multirow[t]{2}{*}{ Switzerland } & $\begin{array}{l}\text { Lombard Odier Darier } \\
\text { Hentsch \& Cie }\end{array}$ & http://www.lombardodier.com & Yes & $2 / 2$ & 4,87 \\
\hline & Pictet \& Cie & http://www.pictet.com & Yes & & \\
\hline TOTAL & 41 Firms & 40 Firms & 9 Firms & $41 / 32$ & 100 \\
\hline
\end{tabular}


In addition, being modern is a final requirement. Created in 1981, the objective of the Association is the development of its membership throughout the world around a common philosophy: the value of the concept of the family company, real alternative to the multinationals. It is not a brotherhood, the sectors in which the members carry on their activities are in fact highly diversified: craft industries, trades, services, publishing, heavy industry. Nor is it a businesses club (certain firms may even be competitors). The Henokiens do not exchange services, they exchange only ideas".

Henokiens is chosen as population of this study since the aim of this study is to observe whether there is a linkage between long time survival and innovation. As members of Henokiens are at least more than two hundred years old, it will be interesting to discover whether innovation is one of the reasons why they survive many years. Surely the findings can not be generalized, and results can only be taken as first insights on the observed phenomena.

Researchers can only understand English, so the Henokiens whose have English web sites will be content analized. All the firms will be analized from general web sites of Henokines if possible as the aim of the study is to discover Henokien's survival and their stress to innovation as long time survival. Table 2, that composed of the Henokien's Web site of http://www.henokiens.com and each firm's individual web sites, shows general characteristics of the population. According to the table, only 32 firms have English web sites, 2 firms's web sites are in their original language, the rest of the firms' have neither web sites nor web pages that can be read due to limited information or difficulties in open their pages. So we extracted 9 firms from the analysis.

As Table 2 indicates majority of the Henokiens are from Italy (36,59\%), others from France $(29,27 \%)$, from Japan $(12,20 \%)$, and Germany $(7,32)$. The rest of the 14.62 percentage is shared among Belgium, Ireland, Netherlands and Switzerland. Considering Japanese firms are only 12,20\% of the whole population, it can be said that the Henokiens are mostly European, and Italian and French firms will dominate the findings of the study.

In order to observe the national distribution of the sample and compare it with the population, and determining the sample size the table below is extracted. According to the table, all the nations within the Henokiens included in the content analysis process, and majority of the firms in the sample are from Italy $(40,64 \%)$, France $(25 \%)$ and Japan $(12,5 \%)$ that means general characteristics of the population is more less the similar in the sample.

\begin{tabular}{|l|c|c|c|}
\hline \multicolumn{5}{|c|}{ Table 3: Population and Sample Size } \\
\hline Country & No. Firms in Total & Sample Size & \% of Sample \\
\hline Germany & 3 & 2 & 6,25 \\
\hline Belgium & 1 & 1 & 3,12 \\
\hline France & 12 & 8 & 25 \\
\hline Ireland & 1 & 1 & 3,12 \\
\hline Italy & 15 & 13 & 40,64 \\
\hline Japan & 5 & 4 & 12,5 \\
\hline Netherlands & 2 & 1 & 3,12 \\
\hline Switzerland & 2 & 2 & 6,25 \\
\hline TOTAL & $\mathbf{4 1}$ & $\mathbf{3 2}$ & $\mathbf{1 0 0}$ \\
\hline
\end{tabular}

\section{FINDINGS}

Table 4 is summarizes all the Henokiens' characteristics in line with their sectors, foundation dates, ages and generations in order to understand general specification of the Henokiens. The youngest firm is 201 years old from France and the oldest one is 1293 years old from Japan. The generation of the firm varies from $6^{\text {th }}$ to $46^{\text {th }}$. The sectors of the firms are all mature industries that some of them in the earlier stage of the globalization. 
Journal of Global Strategic Management | V. 4 | N. 2 | 2010-December | isma.info | 113-125 | DOI: 10.20460/JGSM.2010415829

Table 4: General Characteristics of the Population: Sectors, Foundation Dates and Generation

\begin{tabular}{|c|c|c|c|c|c|}
\hline Country & Name of the firm & Sector & $\begin{array}{c}\text { Foundation Date/ } \\
\text { Age }\end{array}$ & Age & Generation \\
\hline \multirow[t]{3}{*}{ Germany } & Friedr. Schwarze & Alcohol drinks and liquor & 1664 & 346 & 11th \\
\hline & Möller Group & Plastic technology & 1730 & 280 & 8 th \\
\hline & J.d. Neuhaus & Air hoists & 1745 & 265 & 7th \\
\hline Belgium & D'ieteren & Automobile, auto glass & 1805 & 205 & 6th \\
\hline \multirow[t]{12}{*}{ France } & $\begin{array}{l}\text { Banque J.P. Hottinguer } \\
\& \text { Cie }\end{array}$ & Private bank & 1786 & 224 & No information \\
\hline & $\begin{array}{l}\text { Baronnie de } \\
\text { Coussergues }\end{array}$ & Viniculture, wine cellar & 1488 & 522 & No information \\
\hline & Delamare Bois & Wood, lumber merchant & 1690 & 320 & No information \\
\hline & Sfco - Maison Gradis & Maritime trade & 1685 & 325 & No information \\
\hline & Hugel \& Fils & Wine & 1639 & 371 & No information \\
\hline & Louis Latour & Wine & 1797 & 213 & 10th \\
\hline & Editions Henry Lemoine & Music & 1772 & 238 & No information \\
\hline & Mellerio dits Meller & Jeweler & 1613 & 397 & $14^{\text {th }}$ \\
\hline & Revol & Porcelain & 1789 & 221 & No information \\
\hline & Jean roze & Silk cloth & 1756 & 254 & $12^{\text {th }}$ \\
\hline & Thiercelin & Saffron, spices & 1809 & 201 & $7^{\text {th }}$ \\
\hline & Viellard Migeon \& Cie & $\begin{array}{l}\text { Aerospace, automotive, medical, } \\
\text { cosmetics }\end{array}$ & 1679 & $1679 / 331$ & No information \\
\hline Ireland & $\begin{array}{l}\text { William Clark And } \\
\text { Sons, Ltd. }\end{array}$ & Textile & 1736 & 274 & $9^{\text {th }}$ \\
\hline \multirow[t]{15}{*}{ Italy } & Amarelli & Calabria liquorice & 1731 & 279 & No information \\
\hline & Augustea & Maritime trade & 1629 & 381 & No information \\
\hline & Barovier\&to & Glassmanufacturing & 1295 & 715 & No information \\
\hline & Beretta & Firearms manufacturing & 1526 & 484 & 13th \\
\hline & Cartiera Mantovana & Paper, cardboard & 1615 & 395 & No information \\
\hline & Fonderia Campane.. & Bell foundry & 1746 & 264 & No information \\
\hline & Confetti Mario Pelino & Confetti ,sweets and liquorice & 1783 & 227 & No information \\
\hline & Crespi 1797 & Textile & 1797 & 213 & $7^{\text {th }}$ \\
\hline & $\begin{array}{l}\text { Ditta Bortolo Nardini S. } \\
\text { P. A }\end{array}$ & Liquorice & 1779 & 231 & $11^{\text {th }}$ \\
\hline & $\begin{array}{l}\text { Giobatta \& Piero Gar- } \\
\text { bellotto }\end{array}$ & Wine making (wood) & 1775 & 235 & $8^{\text {th }}$ \\
\hline & Falck S.P.A. & Iron - steel & 1700 's ( not clear) & About 310 & No information \\
\hline & $\begin{array}{l}\text { Lanificio G.B. Conte } \\
\text { SPA }\end{array}$ & Wool textile & 1757 & 253 & No information \\
\hline & Monzino 1750 & Musical instruments & 1750 & 260 & $8^{\text {th }}$ \\
\hline & Piacenza & Wool manufacturing & 1733 & 277 & No information \\
\hline & Torrini g.S.R.L. & Jewellery & 1369 & 641 & $\begin{array}{l}\text { Extracted from the } \\
\text { groups }\end{array}$ \\
\hline \multirow[t]{5}{*}{ Japan } & Akafuku & Japanese sweet & 1707 & 303 & $11^{\text {th }}$ \\
\hline & $\begin{array}{l}\text { Gekkeikan Sake Com- } \\
\text { pany }\end{array}$ & Sake & 1637 & 373 & $13^{\text {th }}$ \\
\hline & Hoshi & Hotel & 717 & 1293 & $46^{\text {th }}$ \\
\hline & Okaya & Trade & 1669 & 341 & $13^{\text {th }}$ \\
\hline & Toraya & Japanese confectionery & 1635 & 375 & $17^{\text {th }}$ \\
\hline \multirow[t]{2}{*}{ Netherlands } & De Kuyper & Liquor & 1695 & 315 & No information \\
\hline & Van Eeghen & Food trading & 1632 & 378 & 14th \\
\hline Switzerland & $\begin{array}{l}\text { Lombard Odier Darier } \\
\text { Hentsch }\end{array}$ & Private bank & 1796 & 214 & No information \\
\hline
\end{tabular}


When we analyze the Henokiens and the firms' Web page there are innovation categorization for each firms in Henokiens Page. They introduce some firm by stressing the innovation concept and innovation type. We categorized innovation approaches of the Henokiens in the sample, and linkage each firms make with their survival by content analized each firm's personal web sites and Henokiens web page as in Table 5. As it can be seen from the table, in 27 firms out of 41 in total, innovation concept was not stressed at the Henokiens web page. All the firms in the Henokien's web sites were analized as it is in English in order to observe general attitude of all the firms towards innovation as this may give us an extra opportunity to observe whether innovation is vital for the Henokines. The findings are interesting as it is expected to see many more firms, emphasizing innovation and its role for their very long term survival.

In Firm's own pages, innovation concept and its role for firm's survival are observed and categorized in table 5 below. 19 firms out of 32 firms in the sample stressed innovation concept, and importance of it. The most stressed type of innovation is product and technological innovation, as 20 times representing $62.5 \%$ of the whole sample. When considering the linkage between long term survival and innovation, only about $28 \%$ of the whole sample clearly stresses continuous innovation, and that is the most highlighted item.

\begin{tabular}{|l|c|c|}
\hline \multicolumn{2}{|c|}{ Table 5: Innovation Categorization of the Firms in Web Pages } \\
\hline Innovation Types & Henokiens Web Page & Firm's Own Web page \\
\hline & Frequency & Frequency \\
\hline Continuous Innovation and Constant growth & 3 & 9 \\
\hline Tradition and Innovation & 4 & 6 \\
\hline Product Innovation & 4 & 13 \\
\hline Technological Innovation & 2 & 7 \\
\hline Innovation in Customer/Marketing/Consumer & - & 3 \\
\hline Innovation for Sustainable Development & - & 3 \\
\hline Plant innovation & - & 2 \\
\hline Management Innovation & - & 9 \\
\hline Reputation on innovation and image of quality & - & 3 \\
\hline Innovative raw material & - & 3 \\
\hline Innovative Market leader & - & 3 \\
\hline Innovative for over 200 years & $\mathbf{1 6}$ & $\mathbf{6 2}$ \\
\hline
\end{tabular}

When we recategorized all the findings shown in the Table 5 according to the main aim of the study, we created the table 6 below. The table indicates what stress these 19 firms make on the observed issue, such as which innovation competence and what type of innovation they are specialized for, and how vital they see for their survival. Although only about $59 \%$ of the Henokiens in the sample emphasized innovation, this might be taken as a signal for the importance of the innovation, and might be an indicator of the role of innovation for survival through the centuries in the sample. When focusing on the linkage between innovation and survival through the centuries, it can be clearly seen that continuous innovation and reputation for innovation are the most stressed items. Considering the linkage side of the findings in the Table 6, Interesting Findings is that six of the Henokiens out of 32 stress clearly the fact that they combine tradition and innovation through their survival. Although this finding is parallel with the general web page of the Henokiens, where it is clearly mentioned that "the Henokiens are deeply rooted in the economic realities of the present and they manage their companies with talent, navigating between modernism and tradition, between know-how transmitted from the past and innovation or diversification", generalizability of the statement is not clear as much as it is advocated in the page. Similarly in the interview at Henokiens web page with Monzino Group, the group's leader highlighted innovation exactly with following words: “... longevity is also a result of 
the ability to have a feeling for and to interpret in time what's coming and to be able to innovate so as to offer the market increasingly attractive products, services, policies and image". All these statements and the findings indicate the importance of the innovation for the survival of the Henokiens in the sample on one side, not enough emphasis has been put on innovation on the other side. Furthermore only few firms clearly highlight that their perspective of competition stems from the resource based view. This is another suspect we have as it does not really overlap with the established literature.

Table 6: Reconstruction of the Findings in line with the Aim of the Study

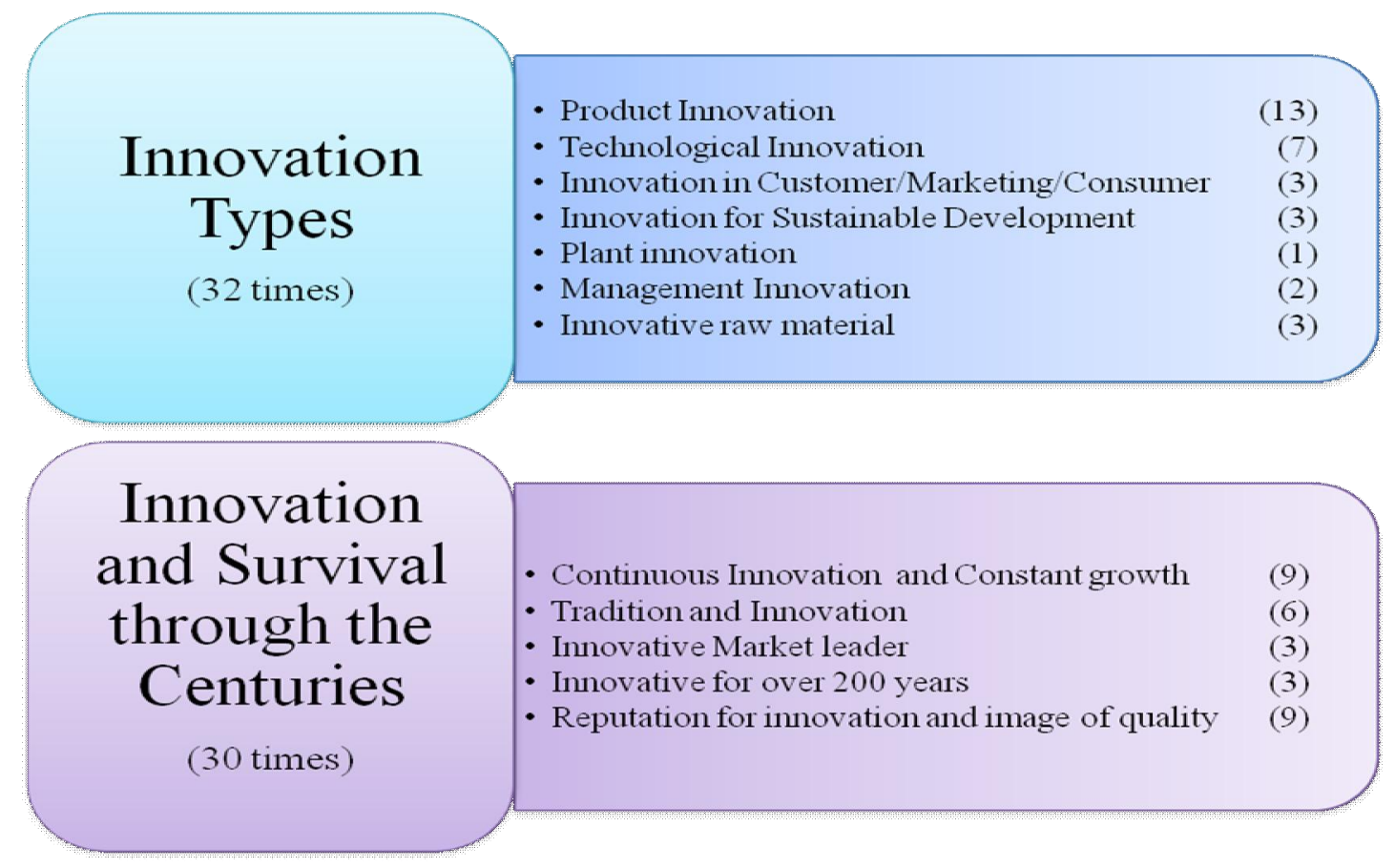

\section{CONCLUSION and DISCUSSION}

In this study we try to focus to explore innovative characteristics of firms surviving through the ages by using content analysis method. We will be analyzing all firms that are listed in the www.henokiens.com. Henokiens is an association that accepts firms which are at least 200 years of age. The 41 firms from different nationalities were analyzed by their web pages' content.

In literature, although innovation is accepted a core concept of survival and sustainable competitive advantage, none of the articles or studies focusing on the linkage between innovation and survival through the centuries found in the literature review searching through the online databases available at libraries and internet. In literature we can summarize 7 different types of Innovation and 5 different points of surviving through ages by being innovative firms. Only Koiranen's (2002) article has been found that seems related to our study. When looking at carefully to the research, an explorative study examining mainly how Finnish family firms rank their business values, only some of the values seem related to innovation indirectly such as intuitive, open, idealistic and self-esteemed. It is interesting to observe no direct and strong emphasis within the business value of these firms, that are over hunderd years of age family firms which is very much smilar to our sample. Adding up all the findings of our study and this study, it can be said that survival for a firm over the centuries may not necessarily depends on innovation competence of the firms. Bakoğlu's (2004) explorative research on growth mechanisms of old goldsmith in Kapalıçarşı, Istanbul, Turkey gives no clear insight for the linkage of long term survival and innovation.

As a result it can be said that it will be too early to inference whether survival through the centuries depends on innovation or not. This study can only be described as one of the pioneer studies that shed some light on the observed phenomena. More researches with different sample and population should 
be done with larger sample size with this purpose. Family firms may have been lasting for over a century some other attributes. A research focusing on the reasons for firm survival for over centuries should be done and literature gap within this area should be covered. Moreover this study may provide to get a line to survive for a firm which wants to live through the centuries. 


\section{REFERENCES}

Agarwal, Rajshree. (1998), Small Firm Survival and Technological Activity, Small Business Economics, 11(3):215-224.

Alderman, Nail. (1996), Innovation and Survival Amongst Mature Establishments in The Mechanical Engineering Industry, Geoforum, 27 (4):461-477.

Amit, R, Schoemaker, J, H. (1993), Strategic Assets and Organizational Rent, Strategic Management Journal, 14(1): 33-46

Audretsch, David B. (1995), Innovation, Growth and Survival, International Journal of Industrial Organization,,13(4): 441.

Bakoğlu, R. (2003), “Kaynak Bazlı Firma Teorisi Kapsamında Değişen Rekabet Avantajı Kavram ve Anlayışı”, İ.Ü. İşletme Fakültesi Dergisi, 32(1), 65-76.

Bakoğlu, R. (2004), Geçmişten Günümüze Kapalı Çarşı Kuyumcularının İş Gelenekleri ve Büyüme Mekanizmaları: Sözlü Tarih Çalışması, I. Aile İşletmeleri Kongresi, İstanbul Kültür Üniversitesi, pp.286-294.

Bakoğlu, R., Aşkun, B. (2008), An Exploratory Research on Innovative Characteristics of the Innovative Firms, 5th International Symposium on Business Administration, Çanakkale, pp.142-154.

Banbury, C.M., Mitchell, W. (1995), The Effect of Introducing Important Incremental Innovations on Market Share and Business Survival, Strategic Management Journal (Summer special issue), 16:161182.

Barney, J. (1986), 'Types of Competition and the Theory of Strategy: Toward an Integrative Framework, Academy of Management Review, 11(4): 791-800.

Barney, Jay B. (1988), Returns to Bidding Firms in Mergers and Acquisitions:

Reconsidering The Related Hypothesis, Strategic Management Journal, 9: 71-78.

Barney, J. (1991), Firm Resources and Sustained Competitive Advantage, Journal of Management, 17 (1): 99-120.

Carroll, Glenn, R, Hannan, M, T. (1989), Density Delay in The Evolution of Organizational Populations: A Model and Five Empirical Tests, Administrative Science Quarterly, 34.

Caves, R.E. (1998), Industrial Organization and New Findings on The Turnover and Mobility of Firms, Journal of Economic Literature, 36 (4): 1947-1982.

Cefis, Elena, Marsili, Orietta. (2005), A Matter of Life and Death: Innovation and Firm Survival, Industrial and Corporate Change, 14 (6):1167-1192.

Cefis, Elena., Marsili, Orietta. (2006), Survivor: The Role of Innovation in Firms'Survival, Research Policy, 35 (5):626-641.

Chrisman, J.J., Chua, J.H. and Shaker, A Zahra. (2003), Creating Wealth in Family Firms Through Managing Resources: Comments and Extensions, Entrepreneurship:Theory and Practice, 27.

Cohen, W, M., Levinthal, D, A. (1990), Absorptive Capacity: A New Perspective on Learning and Innovation, Administrative Science Quarterly, 35: 128-136.

Collis, D.J, Montgomery, C.A, (1995), Competing on Resources: Strategy in The 1990's, Harvard Business Review, 73(4):118-128.

Colombo, M. G. and Delmastro, M. (2001), Technology Use and Plant Closure, Research Policy, 30: 21-34. 
Conner, K.R. (1991), A Historical Comparison of Resource-based Theory and Five Schools of Thought Within Industrial Organization Economics: Do We Have a New Theory of The Firm. Journal of Management, 17: 121-154.

Damanpour, F. (1991), Organizational Innovation: A Meta analysis of effects of determinants and moderators, Academy of Management Journal, 34: 555-590.

Doms, M, Dunne, T, Roberts, Mark J. (1995), The Role of Technology Use in The Survival and Growth of Manufacturing Plants, International Journal of Industrial Organization, 13(4):523-542.

Drucker, P. (1985), Innovation and Entrepreneurship, Harvard Business School, Cambridge, M.A

Ericson, R and Pakes, A, Markov. (1995), Perfect Industry Dynamics: A Framework For Empirical Work, Review of Economic Studies , 62 (1): 53-82.

Geroski, P.A, (1995), What Do We Know About Entry ?, International Journal of Industrial Organization, 13 (4):pp. 421-440.

Goswami, Sanghamitra. Mathew, Mary. (2005), Definition of Innovation Revisited: An Empirical Study on Indian Information Technology Industry, International Journal of Innovation Management, 9,(3): 371-383.

Grant, Robert M. (1991), The Resource-based Theory of Competitive Advantage: Implications For Strategy Formulation, California Management Review, 33(3): 114-135.

Hall, B.H. (1987), The Relationship Between Firm Size and Firm Growth in The US Manufacturing Sector, The Journal of Industrial Economics, 35, (4):pp. 583-606.

Hannan, M, Freeman, J. (1977), The Population Ecology of Organizations, American Journal of Sociology, 82(5):929.

Hannan, M, Freeman, J. (1988), The Ecology of Organizational Mortality: American Labor Unions 1836-1985,, American Journal of Sociology, 94(1):25-52.

Henderson, Rebecca and Cockburn, Iain. (1994), Measuring Competence: Exploring

Firm Effects in Pharmaceutical Research, Strategic Management Journal, 15(8):63-84

Hitt,M.A., Ireland, R.D. ve Hoskisson, R.E. (2005), Strategic Management: Competitiveness and Globalization, 6. Edition, Thomson South-Western, Ohio.

Hofer, Charles, W, Schendel, Don. (1978), Strategy Formulation: Analytical Concepts, St Paul:West Publ

Huergo, Elena., Jaumandreu, Jordi. (2004), How Does Probability of Innovation Change with Firm Age ?, Small Business Economics, 22 (3-4):193-207.

Hult, G, Thomas., Hurley, R.F., Knight, G.A. (2004), Innovativeness: Its Antecedents and Impact on Business Performance, Industrial Marketing Management, 33, (5): pp. 429-438.

Hurley, R., Hult, G,T,M. (1998), Innovation, Market Orientation, and Organizational Learning: An Integration and Empirical Examination, Journal of Marketing, 62: 42-54.

Jaskyte, Kristina., Susana, Maria., Riobo, R,M. (2004), Characteristics of Innovative Nonprofit Organizations in Argentina, Voluntas: International Journal of Voluntary and Nonprofit Organizations, Vol.15, No,1:71-79.

Jovanovic, B, Selection. (1982). The Evolution of Industry, Econometrica, 50 (3): 649-670. 
Kimberly, J.R., Evanisko, M.J. (1981), Organizational Innovation: The Influence of Individual, Organizational, and Contextual Factors on Hospital Adoption of Technological and Administrative Innovations, Academy of Management Journal, 24: 689-713.

Koiranen, M. (2002), Over 100 Years of Age But Still Entrepreneurially Active in Business: Exploring The Values and Family Characterictics of Old Finnish Family Firms, Family Business Review, 15(3): 175-186.

Liao, J., Kickul, J.R. and Ma, H. (2009), Organizational Dynamic Capability and Innovation: An Empirical Examination of Internet Firms, Journal of Small Business Management, 47 (3): 263-307.

Lieberman, M. B. and Montgomery, D.B. (1998), First-Mover (Dis) Advantages: Retrospective and Link with the Resource-Based View, Strategic Management Journal, 19(12): 1111-1125.

Lippman, S.A, Rumelt, R.P. (1982), Uncertain Imitability: An Analysis of Interfirm Differences in Efficiency Under Competition, The Bell Journal of Economics, 13(2):418-438.

Mata, J. and Portugal, P. (1994), Life Duration of New Firms, The Journal of Industrial Economics, 42 (3): $227-245$.

Medina, Cabello, Carmen., Lavado, Antonio, Carmono., Cabrera Ramon, Valle. (2005), Characteristics of Innovative Companies: A Case Study of Companies in Different Sectors, Creativity and Innovation Management, 14 (3): 272 - 287.

Mitchell, W. (1991), Dual Clocks: Entry Order Influences on Incumbent and Newcomer Market Share and Survival When Specialized Assets Retain Their Value, Strategic Management Journal, 12: $85-100$.

Pakes, A. and Ericson, R. (1998), Empirical Implications of Alternative Models of Firm Dynamics, Journal of Economic Theory, 79 (1): 1-45.

Penrose, E.T. (1959), The Theory of The Growth of The Firm, NY. John Wiley

Peteraf, Margareth A. (1993), The Cornerstone of Competitive Advantage: A Resource-based View, Strategic Management Journal, 14:179-191.

Porter, M, E. (1980), Competitive Strategy, NY, Free Press.

Rumelt, R.P. (1991), How much Does Industry Matter ? Strategic Management Journal, 12:167-185.

Selznick, P. (1957), Leadership in Administration: A Sociological Interpretation, Evanston, IL

Sharma, P., Chrisman, J.J., and Chua, J.H. (1997), Strategic Management of The Family Business: Past Research and Future Challenges, Family Business Review, 10(1):1-35.

Sirmon, D.G. and Hitt, M.A. (2003), Managing Resources: Linking Unique Resources, Management and Wealth Creation in Family Firms, Entrepreneurship Theory \& Practice, 27(4): 339-358.

Sutton, J. (1997), Gibrat's legacy, Journal of Economic Literature, 35: 40-59.

Wernerfelt, Birger. (1984), A Resource-Based View of The Firm, Strategic Management Journal, 5, 171-180. 